\title{
ESSENTIAL ELEMENTS IN MATURE HUMAN MILK
}

\author{
Liva Aumeistere ${ }^{1,2 *}$, Inga Ciprovica ${ }^{1}$, Dace Zavadska ${ }^{3}$, Konstantins Bavrins ${ }^{2}$, Anastasija Borisova ${ }^{2}$ \\ $I^{*}$ Faculty of Food Technology, Latvia University of Life Sciences and Technologies, Rigas iela 22, Jelgava, Latvia, \\ e-mail: aumeistere.liva@gmail.com \\ ${ }^{2}$ Institute of Food Safety, Animal Health and Environment BIOR, Lejupes iela 3, Riga, Latvia \\ ${ }^{3}$ Department of Pediatrics, Riga Stradiņš University, Vienibas gatve 45, Riga, Latvia
}

\begin{abstract}
Human milk is recognised as the best source of essential elements for the infant in the first months of life. The objective of research was to determine the content of calcium, iron, magnesium, potassium and selenium in mature human milk. To evaluate possible relation with maternal (age, parity, breastfeeding pattern, dietary intake) and infant's (age, birth weight, sex) attributes. In the study participated 65 lactating women from Latvia (at least one month postpartum). Elements' content in human milk was analysed using ICP-MS (Agilent 7700x, Japan). Dietary data (72-hour food diary) were evaluated using the Fineli Food Composition Database (https://fineli.fi). Data analysis were carried out using IBM SPSS Statistics, version 22.0. Spearman's correlation, partial correlation and Mann-Whitney U test were used to evaluate how maternal \& infant characteristics influence essential elements' content in human milk. Average

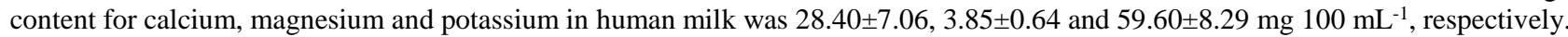
Iron content in $97 \%$ of samples $(\mathrm{n}=63)$ was below detection limit $\left(<0.10 \mathrm{mg} 100 \mathrm{~mL}^{-1}\right)$. Selenium content in all samples was below detection limit $\left(<0.002 \mathrm{mg} 100 \mathrm{~mL}^{-1}\right)$. Calcium content in human milk was affected by breastfeeding pattern - average content of $30.51 \pm 7.31 \mathrm{mg} 100 \mathrm{~mL}^{-1}$ for exclusive breastfeeding and $25.41 \pm 5.43 \mathrm{mg} 100 \mathrm{~mL}^{-1}$ for partial breastfeeding, $\mathrm{p}=0.003$. Dietary intake of essential elements among participants was within recommendations. Our obtained values for calcium, magnesium and potassium in human milk were in accordance with other studies. Further evaluation should be done for the optimisation of the ICP-MS method for the detection of iron and selenium in human milk.
\end{abstract}

Keywords: human milk, essential elements

\section{Introduction}

For the first six months of life, human milk is the most suitable source of essential elements (calcium, potassium, magnesium, iron, selenium) necessary for infant's growth and development (World Health Organization, 2019). These elements are transported from maternal blood to lactocytes and then secreted in milk. This mechanism is closely controlled by mammary epithelial cells to match infant's requirements (Montalbetti et al., 2014; Wysolmerski, 2010).

Calcium is needed for normal development of the skeletal system (bones, teeth) (Bae, Kratzsch, 2018). Calcium content in human milk varies around 20 to $30 \mathrm{mg} 100 \mathrm{~mL}^{-1}$ (EFSA, 2013). To maintain the necessary amount of calcium in milk, maternal bone resorption, intestinal absorption and renal retention of calcium increases. Yet, maternal diet has less impact on calcium level in milk (Bae, Kratzsch, 2018).

Magnesium supports normal muscle and nerve function and is a cofactor in several enzymatic reactions (de la Guardia, Garrigues, 2015; EFSA, 2013). Magnesium content in human milk broadly varies (from

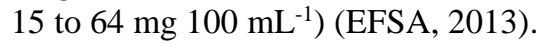

Potassium is the major cation in the human cells, therefore important in maintaining homeostasis. Its content in human milk is $\sim 50 \mathrm{mg} 100 \mathrm{~mL}^{-1}$ (EFSA, 2013).

Iron is the oxygen carrier in the human body (de la Guardia, Garrigues, 2015; EFSA, 2013). The major source of iron during the first six months of life is infant's body stores accumulated during the prenatal period (Friel et al., 2018). Human milk contains a comparatively small amount of iron (0.04-0.10 mg $\left.100 \mathrm{~mL}^{-1}\right)$ but its bioavailability is high (20 to 50\%) (EFSA, 2013; Hale, Hartmann, 2017). Both sources of iron (body stores and human milk) ensure that infant's requirements for iron are satiated for the first six months of life (Friel at al., 2018; Hale, Hartmann, 2017; Montalbetti et al., 2014). After six months, it is recommended to ensure that an infant receives iron-containing complementary foods (Hale, Hartmann, 2017; World Health Organization, 2019). Maternal intake of iron does not affect iron content in human milk (Hale, Hartmann, 2017).

Glutathione peroxidase is a selenium-containing antioxidant enzyme that protects the body against oxidative stress (EFSA, 2013). Selenium is also needed for the synthesis of thyroid hormones and proper functioning of the immune system (Rayman, 2000). Selenium content in human milk is affected by maternal intake of selenium and it significantly varies among women in Europe - from 0.0003 to $0.0084 \mathrm{mg} 100 \mathrm{~mL}^{-1}$ with an average content of $0.003 \mathrm{mg} 100 \mathrm{~mL}^{-1}$ (EFSA, 2013; Hale, Hartmann, 2017). In Latvia's neighbouring country - Estonia, low selenium level in mature human milk samples has been observed (0.0008-0.0029 mg $100 \mathrm{~mL}^{-1}$ ) (Kantola et al., 1997). Zachara and Pilecki (2001) have pointed out that infants in Poland also could receive a lower intake of selenium than recommended. It is potentially due to low selenium content in food products and therefore in the maternal diet (Zachara Pilecki, 2001). Soil fertilisation with sodium selenite in Finland have resulted in an increased intake of selenium among lactating women and therefore in a rise of selenium level in serum and milk, respectively (Kantola et al., 1997). Soils in Latvia are low in bioavailable selenium, therefore food products also could contain a low amount of selenium (Duma et al., 2011).

European Food Safety Authority's (EFSA) opinion as well as recommended daily intakes set by the Ministry 
of Health of the Republic of Latvia on the dietary intake of essential elements for infants and toddlers are compiled in Table 1 (EFSA, 2013; Recommended total energy and nutrient intake among Latvian population, 2017).

Table 1

Dietary intake of essential elements for the infants and toddlers

\begin{tabular}{|c|c|c|}
\hline \multirow[t]{2}{*}{ Element } & Adequate intake ${ }^{1}$ & $\begin{array}{c}\text { Recommended } \\
\text { daily intake }\end{array}$ \\
\hline & mg per day & mg per day \\
\hline \multirow{6}{*}{ Potassium } & $400^{1}$ & n.i. ${ }^{3}$ \\
\hline & ( 0 to $>6$ months old $)$ & ( 0 to 6 months old) \\
\hline & $800^{1}$ & $1100^{2}$ \\
\hline & (6 to<12 months old) & ( 7 to 12 months old) \\
\hline & $800^{1}$ & $1600^{2}$ \\
\hline & (12 to<36 months old) & (1 to 3 years old) \\
\hline \multirow{6}{*}{ Calcium } & $200^{1}$ & n.i. ${ }^{3}$ \\
\hline & ( 0 to $>6$ months old $)$ & (0 to 6 months old) \\
\hline & $400^{1}$ & $550^{2}$ \\
\hline & ( 6 to $<12$ months old) & ( 7 to 12 months old) \\
\hline & $600^{1}$ & $600^{2}$ \\
\hline & (12 to<36 months old) & (1 to 3 years old) \\
\hline \multirow{6}{*}{ Magnesium } & $25^{1}$ & n.i. ${ }^{3}$ \\
\hline & ( 0 to $>6$ months old $)$ & ( 0 to 6 months old) \\
\hline & $80^{1}$ & $60^{2}$ \\
\hline & ( 6 to $<12$ months old) & ( 7 to 12 months old) \\
\hline & $85^{1}$ & $100^{2}$ \\
\hline & (12 to <36 months old) & (1 to 3 years old) \\
\hline \multirow{6}{*}{ Iron } & $0.3^{1,4}$ & n.i. ${ }^{3}$ \\
\hline & $(0$ to $>6$ months old $)$ & (0 to 6 months) \\
\hline & $8^{1}$ & $8^{2}$ \\
\hline & ( 6 to $<12$ months old) & ( 7 to 12 months) \\
\hline & $8^{1}$ & $8^{2}$ \\
\hline & (12 to<36 months old) & (1 to 3 years) \\
\hline \multirow{6}{*}{ Selenium } & $0.0125^{1}$ & n.i. ${ }^{3}$ \\
\hline & ( 0 to $>6$ months old $)$ & (0 to 6 months old) \\
\hline & $0.0150^{1}$ & $0.0150^{2}$ \\
\hline & ( 6 to $<12$ months old) & ( 7 to 12 months old) \\
\hline & $0.0200^{1}$ & $0.0200^{2}$ \\
\hline & (12 to<36 months old) & (1 to 3 years old) \\
\hline \multicolumn{3}{|c|}{$1-$ EFSA, 2013} \\
\hline \multirow{2}{*}{\multicolumn{3}{|c|}{$\begin{array}{l}2 \text { - Recommended total energy and nutrient intake among } \\
\text { Latvian population, } 2017\end{array}$}} \\
\hline & & \\
\hline \multicolumn{3}{|c|}{${ }^{4}$ - breastfed infants } \\
\hline
\end{tabular}

Different methods have been used for the detection of elements in human milk like atomic absorption spectrometry (AAE), flame atomic emission spectrometry (FAES), inductively coupled plasma optical emission spectrometry (ICP-OES) and inductively coupled plasma mass spectrometry (ICP-MS). ICP-MS is the most suitable method to measure elements in human milk due to its ability to simultaneously measure several elements even if they are found in trace amounts (de la Guardia, Garrigues, 2015; Levi et al., 2018).

The majority of essential elements in human milk are independent of maternal intake, nutritional requirements for certain nutrients during lactation raises (Hale, Hartmann, 2017; Segura et al., 2016). Recommended intake of potassium, magnesium and iron among lactating women is the same as for non-lactating but guidelines developed by the Ministry of Health of the Republic of Latvia suggest that intake of calcium and selenium should be increased during lactation (see Table 2) (Recommended total energy and nutrient intake among Latvian population, 2017).

Table 2

Guidelines for daily essential elements' intake among women in Latvia ${ }^{1}$

\begin{tabular}{lcc}
\hline Element & $\begin{array}{c}\text { Non-lactating } \\
\text { women }\end{array}$ & $\begin{array}{c}\text { Lactating } \\
\text { women }\end{array}$ \\
\cline { 2 - 3 } mg per day & mg per day \\
\hline Potassium & 3100 & 3100 \\
Calcium & 800 & 900 \\
Magnesium & 280 & 280 \\
Iron & 15 & 15 \\
Selenium & 0.05 & 0.06 \\
\hline 1- Recommended total energy and nutrient intake among \\
Latvian population, 2017
\end{tabular}

Previously essential elements' content hasn't been sufficiently analysed in Latvia. Therefore, the aim of this study was to determine the content of calcium, iron, magnesium, potassium and selenium in mature human milk and to evaluate possible relation with maternal (age, parity, breastfeeding pattern, dietary intake) and infant's (age, birth weight, sex) attributes.

\section{Materials and Methods}

This cross-sectional study was conducted from November 2016 to December 2017. Overall, 65 lactating women from Latvia (at least one month postpartum) took part in the study. Maternal (age, parity, breastfeeding pattern) and infant's (age, birth weight, sex) characteristics were compiled using a questionnaire and are summarized in Table 3.

Table 3

Characteristics of the participants $(n=65)$

\begin{tabular}{|c|c|c|}
\hline Characteristic & Average \pm SD $^{1}$ & Range \\
\hline \multicolumn{3}{|c|}{ Maternal } \\
\hline Age, years & $31 \pm 4$ & $23-39$ \\
\hline Parity & $2 \pm 1$ & $1-4$ \\
\hline \multicolumn{3}{|c|}{ Infants \& toddlers } \\
\hline Age, months & $6 \pm 4$ & $2-21$ \\
\hline Sex & \multicolumn{2}{|c|}{31 girls, 34 boys } \\
\hline Birth weight, $\mathrm{kg}$ & $3.51 \pm 0.59$ & $1.60-5.36$ \\
\hline \multicolumn{3}{|c|}{ Breastfeeding pattern according to infants \& toddlers ag } \\
\hline Exclusively & \multicolumn{2}{|c|}{36 infants ( 1 to 6 months old) } \\
\hline breastfed & \multicolumn{2}{|c|}{2 infants (6 to 12 months old) } \\
\hline Partially breastfed & \multirow{3}{*}{\multicolumn{2}{|c|}{$\begin{array}{l}4 \text { infants ( } 1 \text { to } 6 \text { months old }) \\
19 \text { infants ( } 6 \text { to } 12 \text { months old }) \\
4 \text { toddlers ( }>12 \text { months old })\end{array}$}} \\
\hline & & \\
\hline & & \\
\hline
\end{tabular}

Participating women filled a 72-hour food diary and obtained a pooled human milk sample in the next 24 hours $(\sim 10 \mathrm{~mL})$. Mothers were allowed to choose the most convenient method for milk expression 18 participants used manual method (by hand), 
38 participants used breast pump but 9 participants combined both methods.

Participants expressed few millimetres of milk after the breastfeeding session. Sampling capacity was not specified but the pooled sample had to include morning, mid-day and evening feedings' milk. Milk was collected into non-sterile propylene container (Plastiques Gosselin, France). Participants were instructed to keep samples refrigerated $\left(+4 \pm 2{ }^{\circ} \mathrm{C}\right)$ during sampling and afterwards place the container into a freezer $\left(-18^{\circ} \mathrm{C}\right)$. Then samples were transported to the laboratory (using a cooler with ice packs) and kept frozen until the analysis $\left(-18 \pm 3{ }^{\circ} \mathrm{C}\right)$.

Elements' $\left({ }^{39} \mathrm{~K},{ }^{43} \mathrm{Ca},{ }^{24} \mathrm{Mg},{ }^{56} \mathrm{Fe},{ }^{78} \mathrm{Se}\right)$ content in human milk was analysed using ICP-MS, according to manufacturer's (Agilent 7700x, Japan) instructions.

Dietary data (a 72-hour food diary) were evaluated using the Fineli Food Composition Database (https://fineli.fi) and exported to the MS Excel 2013. Unfortunately, we were unable to use the Latvian Food Composition Database to calculate essential elements' intake among participants. Taking into account that in the 1990s, soils in Finland were fertilised with sodium selenite (Kantola et al., 1997), food products from Finland should contain higher amounts of selenium than products from Latvia and our calculated results for selenium intake among participants from Fineli Food Composition Database could be overestimated.

Approximately one-third of the participants $(n=20)$ noted the use of nutritional supplements containing at least one of the evaluated elements. Information about essential elements' content in nutritional supplements was taken from the Food and Veterinary Service's Register of Nutritional Supplements (https://registri.pvd.gov.lv/ub) and counted to the data calculated from the Fineli Food Composition Database.

Data analysis were carried out using IBM SPSS Statistics, version 22.0. Spearman's correlation, partial correlation and Mann-Whitney $U$ test were used to evaluate how maternal \& infant characteristics influence essential elements' content in human milk $(\mathrm{p}<0.05)$.

Prior to the study, approval from Riga Stradiňš Ethic Committee was received (No. 4/28.7.2016). All the women signed written consent.

\section{Results and Discussion}

This is one of the first reports determining essential elements' content in human milk along with the dietary assessment of essential elements' intake among women in Latvia. Average content for calcium, magnesium and potassium in human milk was $28.40 \pm 7.06,3.85 \pm 0.64$ and $59.60 \pm 8.29 \mathrm{mg} 100 \mathrm{~mL}^{-1}$, respectively. Iron content in $97 \%$ of samples $(n=63)$ was below detection limit $\left(<0.10 \mathrm{mg} 100 \mathrm{~mL}^{-1}\right)$. Selenium content in all samples was below detection limit $\left(<0.002 \mathrm{mg} 100 \mathrm{~mL}^{-1}\right.$ ) (see Table 4).
Table 4

Essential elements' content in mature human milk according to infant's $\&$ toddler's age $(n=65)$

\begin{tabular}{|c|c|c|c|}
\hline \multirow[t]{2}{*}{ Element } & Age & Average \pm SD & $\begin{array}{c}\text { Detection } \\
\text { limit }{ }^{1}\end{array}$ \\
\hline & months & $\mathrm{mg} 100 \mathrm{~mL}^{-1}$ & $\mathrm{mg} 100 \mathrm{~mL}^{-1}$ \\
\hline Potassium & $\begin{array}{c}0 \text { to } 6 \\
\geq 6\end{array}$ & $\begin{array}{l}60.83 \pm 7.54 \\
57.48 \pm 9.06\end{array}$ & 0 \\
\hline Calcium & $\begin{array}{l}0 \text { to } 6 \\
\geq 6\end{array}$ & $\begin{array}{l}30.91 \pm 7.45 \\
25.31 \pm 5.66\end{array}$ & 0.20 \\
\hline Magnesium & $\begin{array}{l}0 \text { to } 6 \\
\geq 6\end{array}$ & $\begin{array}{l}3.96 \pm 0.67 \\
3.69 \pm 0.59\end{array}$ & 2 \\
\hline Iron & $\begin{array}{c}0 \text { to } 6 \\
\geq 6\end{array}$ & $\mathrm{BDL}^{2}$ & 0.10 \\
\hline Selenium & $\begin{array}{l}0 \text { to } 6 \\
\geq 6\end{array}$ & $\mathrm{BDL}^{2}$ & 0.002 \\
\hline
\end{tabular}

1 - based on $20 \times$ standard deviation of method blanks, $2.5 \mathrm{~mL}$ analytical portion and $50 \mathrm{~mL}$ analytical solution.

2 - below the detection limit

Our obtained average results for calcium (28.40 mg $\left.100 \mathrm{~mL}^{-1}\right)$, potassium $\left(59.60 \mathrm{mg} 100 \mathrm{~mL}^{-1}\right)$ and magnesium content $\left(3.85 \mathrm{mg} 100 \mathrm{~mL}^{-1}\right)$ in human milk was within range reported from other studies (16-35 mg $100 \mathrm{~mL}^{-1}$ for calcium, 33-71 mg $100 \mathrm{~mL}^{-1}$ for potassium and $1.6-5.0 \mathrm{mg} 100 \mathrm{~mL}^{-1}$ for magnesium) (de la Guardia, Garrigues, 2015).

Calcium content in human milk significantly correlated with potassium $(\mathrm{r}=0.471, \mathrm{p}=0.000)$ and magnesium content $(r=0.307, p=0.013)$. Calcium content in human milk was affected by breastfeeding pattern - average content of $30.51 \pm 7.31 \mathrm{mg} 100 \mathrm{~mL}^{-1}$ for exclusive breastfeeding and $25.41 \pm 5.43 \mathrm{mg} 100 \mathrm{~mL}^{-1}$ for partial breastfeeding, $\mathrm{p}=0.003$. Other characteristics (maternal age, parity, infant's age, birth weight, sex) did not influence essential elements' content in milk ( $p>0.05$ ).

World Health Organization recommends that infants should be breastfed till six months of age. After that, complementary foods should be introduced into an infant's diet but breastfeeding should be continued till two years of age and beyond (World Health Organization, 2019). To evaluate if exclusively breastfed infants till six months of age in Latvia receive sufficient intake of essential elements, we selected exclusively breastfed infants till six months of age among our participants $(n=36)$, calculated average values for essential elements' content in human milk and multiplied it with the average amount of daily consumed milk ( 780 mL, according to EFSA, 2013). Calculations were compared to the intake of essential elements which are considered adequate for the majority of infants according to EFSA (EFSA, 2013) (see Table 1). Results are summarized in Table 5 and show that exclusively breastfed infants in Latvia receive sufficient amounts of potassium, calcium and magnesium.

Partially breastfed infants from 7 to 12 months on average consume $\sim 520 \mathrm{~mL}$ of human milk per day (World Health Organization, 1998). After six months of age, human milk is still an important source of essential elements, providing $\sim 32 \%$ of magnesium, $\sim 25 \%$ 
calcium and $\sim 28 \%$ of the recommended daily intake of potassium (Table 5).

Table 5

Calculated consumed amount of essential elements among participating infants $(n=55)$

\begin{tabular}{|c|c|c|}
\hline \multirow{2}{*}{ Element } & $\begin{array}{c}\text { Intake via } \\
\text { human milk }\end{array}$ & Recommendation \\
\hline & mg per day & mg per day \\
\hline \multicolumn{3}{|c|}{ Exclusively breastfed infants till 6 months of age $(n=36)$} \\
\hline Potassium & 474 & $400^{1}$ \\
\hline Calcium & 241 & $200^{1}$ \\
\hline Magnesium & 31 & $25^{1}$ \\
\hline \multicolumn{3}{|c|}{$\begin{array}{l}\text { Partially breastfed infants from } 7 \text { to } 12 \text { months of age } \\
\qquad(\mathrm{n}=19)\end{array}$} \\
\hline Potassium & 307 & $1100^{2}$ \\
\hline Calcium & 137 & $550^{2}$ \\
\hline Magnesium & 19 & $60^{2}$ \\
\hline
\end{tabular}

While advancement in technologies allows us to determine trace amounts of elements in human milk, researchers are still faced with some difficulties. Currently, there is no suitable reference material to check the accuracy for obtained results in human milk. An acid digestion preparation was used prior to the ICP-MS analysis in our study. Levi et al. (2018) have observed that the concentration of selenium in the human milk samples were higher $(\sim 15 \%)$ with the alkali dilution method in contrast to the acid digestion but a higher iron concentration $(\sim 28 \%)$ in human milk were obtained using acid digestion method, respectively. Therefore, the selection of sample preparation method for human milk should be chosen according to the selected elements (Levi et al., 2018). Our obtained detection limits for iron and selenium were significantly higher compared to Björklund et al. (2012), who reported $100 \mu \mathrm{g}$ vs $0.16 \mu \mathrm{g} 100 \mathrm{~mL}^{-1}$ for iron, $2 \mu \mathrm{g}$ vs $0.06 \mu \mathrm{g} 100 \mathrm{~mL}^{-1}$ for selenium. Although it should be noted that their limit of detection was based only on five blank samples while ours - on 20 blank samples.

Detection of selenium $\left({ }^{78} \mathrm{Se}\right)$ and iron $\left({ }^{56} \mathrm{Fe}\right)$ isotopes using ICP-MS could also be influenced by spectrometric interferences with other polyatomic ions, mostly argon ions (de la Guardia, Garrigues, 2015). Argon was used as a carrier gas for ICP-MS analysis in our study.

Further evaluation should be done for the optimisation of the ICP-MS method for the human milk analysis to decrease detection limits for iron and selenium isotopes. During lactation, mothers should consume a wellbalanced diet to restore nutrients lost due to milk synthesis (Hale, Hartmann, 2017). We asked our participants to complete a 72-hour food diary. Average daily intake of evaluated essential elements among participants was within recommended ranges (Table 6). Dietary potassium, calcium and magnesium intake did not influence the content of these elements in milk, respectively.
Table 6

Essential elements' intake among participating women $(n=65)$

\begin{tabular}{llc}
\hline \multirow{2}{*}{ Element } & \multicolumn{1}{c}{ Average intake \pm SD } & $\begin{array}{c}\text { Recommended } \\
\text { daily intake }\end{array}$ \\
\cline { 2 - 3 } & \multicolumn{1}{c}{ mg per day } & mg per day \\
\hline Potassium & $3862.42 \pm 2001.55$ & 3100 \\
Calcium & $1002.25 \pm 570.13$ & 900 \\
Magnesium & $398.90 \pm 187.13$ & 280 \\
Iron & $16.92 \pm 15.16$ & 15 \\
Selenium & $0.09 \pm 0.05$ & 0.06 \\
\hline
\end{tabular}

$\overline{1-\text { Recommended total energy and nutrient intake among }}$ Latvian population, 2017

Correlation coefficients between dietary intake and content of elements in human milk were $r=-0.041$ $(\mathrm{p}=0.747)$ for potassium, $\mathrm{r}=-0.012 \quad(\mathrm{p}=0.924)$ for calcium, $r=0.117(p=0.355)$ for magnesium. This is consistent with the data from other studies (Bravi et al., 2016; Hale, Hartmann, 2017). Dietary intake of iron and selenium among participants was also within recommended ranges but obtained values of these elements in milk were below detection limit. Therefore, we could not calculate correlations between maternal intake of iron and selenium and content of these elements in milk, respectively.

\section{Conclusions}

Exclusively breastfed infants till six months of age receive sufficient amount of potassium, calcium and magnesium. After the first half of year, human milk is still an important source of essential elements for the infant.

Dietary intake of evaluated essential elements among participating women was within recommendations developed by the Ministry of Health of the Republic of Latvia.

The Ministry of Health of the Republic of Latvia should develop recommendations regarding essential elements' intake for 0 to 6 months old infants.

Further evaluation should be done for the optimisation of the ICP-MS method for the detection of iron and selenium in human milk.

\section{Acknowledgement}

This study has received financial support from the programme "Strengthening Research Capacity in the Latvia University of Life Sciences and Technologies". Project No. Z-2, Contract No. 3.2.-10/44. We are thankful to all the women who took part in the research and donated human milk samples.

\section{References}

1. Bae Y.J., Kratzsch J. (2018) Vitamin D and calcium in the human breast milk. Best Practice \& Research Clinical Endocrinology \& Metabolism, Vol. 32, p. 39-45.

2. Björklund K.L., Vahter M., Palm B., Grandér M., Lignell S., Berglund M. (2012) Metals and trace element concentrations in breast milk of first time healthy mothers: a biological monitoring study. Environmental Health, Vol. 11(92), p. 1-8. 
3. Bravi F., Wiens F., Decarli A., Dal Pont A., Agostoni C., Ferraroni M. (2016) Impact of maternal nutrition on breast-milk composition: a systematic review. American Journal of Clinical Nutrition, Vol. 104, p. 646-662.

4. de la Guardia M., Garrigues S. (2015) Handbook of Mineral Elements in Foods. UK: John Wiley \& Sons, $792 \mathrm{p}$.

5. Duma M., Alsina I., Dubova L., Stroksa L., Smiltina Z. (2011). The effect of sodium selenite and selenate on the quality of lettuce. In: $11^{\text {th }}$ Baltic Conference on Food Science and Technology "Food science and technology in a changing world" FOODBALT 2017 Conference proceedings, Jelgava, Latvia, p. 39-44.

6. European Food Safety Authority (EFSA) (2013). Scientific Opinion on nutrient requirements and dietary intakes of infants and young children in the European Union. [accessed on 01.02.2019.]. Available at: https://efsa.onlinelibrary.wiley.com/doi/epdf/10.2903/j.e fsa. 2013.3408

7. Food and Veterinary Service. Register of Nutritional Supplements. [accessed on 02.02.2019.]. Available at: https://registri.pvd.gov.lv/ub

8. Friel J., Qasem W., Cai C. (2018) Iron and the Breastfed Infant. Antioxidants, Vol. 7(54), p. 1-8.

9. Hale T.W., Hartmann P. (2017) Textbook of Human Lactation. New York: Springer Publishing Company, $661 \mathrm{p}$.

10. Kantola M., Mand E., Viitak A., Juravskaja J., Purkunen R., Vartiainen T., Saarikoski S., Pasanen M. (1997) Selenium contents of serum and human milk from Finland and neighbouring countries. The Journal of Trace Elements in Experimental Medicine, Vol. 10, p. 225-232.

11. Levi M., Hjelm C., Harari F., Vahter M. (2018) ICP-MS measurement of toxic and essential elements in human breast milk. A comparison of alkali dilution and acid digestion sample preparation methods. Clinical Biochemistry, Vol. 53, p. 81-87.

12. Montalbetti N., Dalghi M.G., Albrecht C., Hediger M.A. (2014) Nutrient transport in the mammary gland:
Calcium, trace minerals and water soluble vitamins. Journal of Mammary Gland Biology and Neoplasia, Vol. 19, p. 73-90.

13. Rayman M.P. (2000) The importance of selenium to human health. Lancet, Vol. 356(9225), p. 233-241.

14. Segura S.A., Ansótegui J.A., Díaz-Gómez M., en representación del Comité de Lactancia Materna de la Asociación Espa nola de Pediatría (2016) The importance of maternal nutrition during breastfeeding: Do breastfeeding mothers need nutritional supplements? Anales de Pediatría, Vol. 84(6), p. 347.e1-347.e7.

15. The Ministry of Health of the Republic of Latvia. Recommended total energy and nutrient intakes among Latvian population, 2017. [accessed on 01.02.2019.]. Available at: http://www.vm.gov.lv/images/userfiles/ Tava\%20veseliba/Ieteicam\%C4\%81s_ener\%C4\%A3ijas _un_uzturvielu_devas.pdf in Latvian)

16. The nutrition unit of the National Institute for Health and Welfare. The Fineli Food Composition Database Release 19 (March 3, 2018). [accessed on 02.02.2019.]. Available at: https://fineli.fi/fineli/en/index

17. World Health Organization (1998) Complementary Feeding of young Children in Developing Countries: a Review of Current Scientific Knowledge. [accessed on 04.02.2019.]. Available at: https://apps.who.int/iris/handle/10665/65932

18. World Health Organization. Breastfeeding. [accessed on 01.02.2019.]. Available https://www.who.int/topics/breastfeeding/en/

19. Wysolmerski J.J. (2010) Interactions between breast, bone, and brain regulate mineral and skeletal metabolism during lactation. Annals of the New York Academy of Sciences, Vol. 1192, p. 161-169.

20. Zachara B.A., Pilecki A. (2001) Selenium concentration in the milk of breast-feeding mothers and its geographic distribution. Environmental Health Perspectives, Vol. 108(11), p. 1043-1046. 